\title{
BELFAST RADIOCARBON DATES I
}

A. G. SMITH, G. W. PEARSON, and J. R. PILCHER

Palaeoecology Laboratory, Queen's University, Belfast, Northern Ireland

INTRODUCTION

The dating equipment in the Queen's University Palaeoecology Laboratory was installed to provide data for research projects, initially dealing with the development of agriculture, in the departments of Botany and Archaeology.

The dates reported have been obtained using a 2.2-L copper proportional counter filled with a constant mass of methane equivalent to an absolute pressure of $380 \mathrm{~cm} \mathrm{Hg}$ at $20^{\circ} \mathrm{C}$. Background varies inversely with barometric pressure $(0.060$ counts $/ \mathrm{min} / \mathrm{mb}$ : correlation coefficient0.95 ). The background count corrected to $1000 \mathrm{mb}$ is 10.25 counts $/ \mathrm{min}$. The net count rate for $95 \%$ of the NBS oxalic acid standard is 51.85 counts $/ \mathrm{min}$.

The $\mathrm{CO}_{2}$ from combustion of the sample is converted to $\mathrm{CH}_{4}$, on a ruthenium catalyst, using a Radiochemistry Inc. sample converter. The catalytic reactor, which is of a flow type, has been redesigned for cartridge loading of the catalyst pellets and to provide a reliably leak-tight system. Gas purity is monitored by determining the pulse amplitude arising from the absorption of the $\gamma$ emission from an external $\mathrm{Cs}^{137}$ source in a standard geometry. This was previously compared to the $\mathrm{C}^{14}$ spectrum obtained from the detector using a known-high-purity methane that gave a gross plateau length of more than $1000 \mathrm{v}$. Our experience is that the Radiochemistry converter, as supplied, does not routinely produce gas of sufficiently high purity. The methane is, therefore, finally passed over a palladium catalyst in the presence of a small amount of hydrogen to remove electronegative impurities, particularly oxygen. Other modifications include additional pumping facilities and the transfer of the Radiochemistry detector assembly to a concrete-lined pit covered by $20 \mathrm{~cm}$ of old iron. The detector is surrounded by a $2.5-\mathrm{cm}$ cylindrical mercury shield and a copper multiple-anode proportional guard counter which is filled to $152 \mathrm{~cm}$ with methane. Surrounding this is a $10-\mathrm{cm}$ lead-shot shield.

The counting system consists of pre-amplifiers, main amplifiers, and anticoincidence circuitry supplied by Baird-Atomic Europe N.V. (Model LB 231) incorporating triple blanking from the guard/antenna channel and the $\alpha$-channel. This unit feeds the scaler section of a spectrometer supplied by Baird-Atomic Inc. (Model 560), which also supplies the high voltage. The scaler pulses are fed into a Beckman (Model $1453 \mathrm{H}$ ) printer which is set to print at 10 min intervals to enable a statistical check to be made. The electronics are checked routinely using the internal test program together with simulated proportional pulses from a pulse generator. These pulses are fed into the guard and detector amplifier inputs to check 
on amplifier gain and discriminator levels. The operating voltage is 5.2 $\mathrm{kv}$. The channel width is selected, on the basis of the oxalic acid standard, to include the optimum number of $\mathrm{C}^{11} \beta$ pulses with minimum background. A check on the channel width is obtained by measuring the number of counts from the external $\mathrm{Cs}^{137}$ source at different high-voltage settings above the gross and $\alpha$ discriminators. The samples have been counted for $1000 \mathrm{~min}$ at least twice, at roughly 14-day intervals (except UB-67 and UB-206).

The charcoal samples have been pretreated in the following way:

1) boiled in $10 \% \mathrm{NaOH}$ for 1 hour and washed;

2) bleached in calcium hypochlorite, acidified with $\mathrm{HCl}$, and washed;

3) nitrated in a 1:1 mixture of conc $\mathrm{H}_{2} \mathrm{SO}_{4}$ and conc $\mathrm{HNO}_{3}$ and washed;

4) extracted in redistilled acetone in Soxhlet extractor until issuing solvent is clear;

5) extracted in water in Soxhlet;

6) dried for 3 days at $100^{\circ} \mathrm{C}$.

\section{ACKNOWLEDGMENTS}

We gratefully acknowledge financial support from The Queen's University of Belfast and the Natural Environment Research Council. We are much indebted for advice on technical matters to E. H. Willis, V. R. Switsur, H. Barker, and A. Walton, and would like to thank H. Tauber and R. Burleigh for providing check samples. A special debt is owed to G. Moffatt and A. Richardson for their early work in attempting to bring the apparatus into operation. We acknowledge the cooperation in the field of D. M. Waterman and A. M. ApSimon in obtaining samples from Navan Fort and Ballynagilly. The sample descriptions and comments for Navan Fort have been written in collaboration with Waterman, and ApSimon has contributed to the comments on the Ballynagilly dates. We are indebted to P. Q. Dresser for his work on the barometric pressure correction and to I. Goddard for general assistance. E. M. Jope has given us the benefit of his advice and guidance throughout.

\section{SAMPLE DESCRIPTIONS}

I. CHECK SAMPLES

UB-63. Fallahogy, No. 6

$4110 \pm 55$

2160 в.c.

Sphagnum peat from raised bog in Townland of Fallahogy, Co. Londonderry, Northern Ireland (54 $54^{\prime} 30^{\prime \prime} \mathrm{N}$ Lat, $6^{\circ} 33^{\prime} 5^{\prime \prime} \mathrm{W}$ Long; Irish Grid Ref. C 925075). Sample from $227 \mathrm{~cm}$ depth immediately above main retardation layer and at beginning of 2 nd phase of forest clearance as indicated by pollen analysis (Smith and Willis, 1962). Coll. 1957 by A.G.S. Comment: part of this sample was dated by the Cambridge Laboratory (Radiocarbon, 1962, v. 4, p. 68) Q-558; $4582 \pm 120,4492 \pm 120$, $4398 \pm 120$ B.P. No pretreatment. 
UB-65. Mentuhotep, Thebes

Sec. of tree trunk from mortuary temple of Neb-hepet-Re Mentuhotep (XIth Dynasty) at Deir el Bahri, Thebes (25 $44^{\prime} \mathrm{N}$ Lat, $32^{\circ} 38^{\prime} \mathrm{E}$ Long), Egypt. Found by Egypt Exploration Fund 1907 and now in Dept. of Egyptian Antiquities, British Mus., No. 4779. Expected age, 2010 в.c. (3960 B.P.), is based on astronomical evidence and should not be more than $20 \mathrm{yr}$ in error. Comment: part of this sample was dated by the British Mus. Lab. (Radiocarbon, 1959, v. 1, p. 85) BM-21, $3580 \pm 150$ B.P. Acid pretreatment.

\section{UB-64. Ruds Vedby, Denmark}

$10,875 \pm 70$ 8925 B.C.

Wood from thin dark layer representing Pollen Zone Boundary II/ III, Aller $\phi \mathrm{d} /$ Younger Dryas. Isolated from peaty lake mud in profile at Ruds Vedby, Zealand, Denmark (55 $33^{\circ} \mathrm{N}$ Lat, $11^{\circ} 22^{\prime} \mathrm{E}$ Long). Comment: this material, extensively used as interlaboratory check sample, has been dated 13 times by 9 labs. Dates are summarized by Håkansson (Radiocarbon, 1968, v. 10, p. 38) who gives weighted mean of those measurements made before his own (Lu-3, 10,840 \pm 120$)$ as 10,995 \pm 55 . No pretreatment.

UB-67. 1835-1845 larch wood

$160 \pm 100$

Wood from A.D. 1835-1845 rings of larch tree felled in 1964 at Pomeroy Forestry School, Co. Tyrone, Northern Ireland $\left(54^{\circ} 35^{\prime} \mathrm{N}\right.$ Lat, $6^{\circ} 54^{\prime} \mathrm{W}$ Long; Irish Grid Ref. H 705724). Coll. 1964 by A.G.S. Comment: carbonized before combustion.

\section{ARCHAEOLOGIC SAMPLES}

\section{Navan Fort series, Co. Armagh, Northern Ireland}

Samples are from Navan Fort $\left(54^{\circ} 21^{\prime} \mathrm{N}\right.$ Lat, $6^{\circ} 41^{\prime} \mathrm{W}$ Long; Irish Grid Ref. H 847452) under excavation by D. M. Waterman, Archaeol. Survey of Northern Ireland. After Neolithic utilization, there was a circular habitation enclosure with ditch (UB-188) and palisade, of Late Bronze age to Early Iron age date. Remains of settlement consist of series of wall-slots of 3 circular houses (UB-203). A soil which developed towards end of occupation (UB-187) underlies clean stratum suggesting period of disuse. A massive concentric-ring timber structure, $40 \mathrm{~m}$ in liam., was then erected, reconstructed, and burnt, apparently deliberately (UB-186 and UB-202). Finally, a composite mound $46 \mathrm{~m}$ in diam. and 4.5 to $5 \mathrm{~m}$ high was constructed. Coll. by D. M. Waterman following field discussion with A.G.S. and J.R.P.

\section{UB-188. Navan Fort, primary ditch fill}

$$
\begin{gathered}
2630 \pm 50 \\
680 \text { B.C. }
\end{gathered}
$$

Charcoal from base of primary ditch filling. Comment: should date earliest occupation within ditch. Date suggests circular enclosure was in 
use by end of Bronze age. Blade of a bronze socketed-sickle was discovered in cobbling assoc. with round houses.

\section{UB-203. Navan Fort, wall slot of Phase 2 house 410 B.c.}

Charcoal (partly Fraxinus, id. by J.R.P.) from wall of Phase 2 timber round house. From rebuilding near end of series. Comment: material may be debris from earlier building in Phase 2, but date should be applicable to Phase 2 in general.

\section{UB-187. Navan Fort, surface of ditch filling}

$2345 \pm 50$

Charcoal from above natural silting of ditch at base of soil which developed towards end of occupation of circular enclosure. Comment: sample does not relate to final occupation of circular enclosure, but can be taken with UB-188 and UB-203 as applicable to occupation of circular habitation enclosure in general.

UB-186. Navan Fort, concentric-ring post structure, 1

$2415 \pm 50$

465 B.C.

Charcoal (Quercus, id. by J.R.P.) from destruction layer of periphery of 40-m concentric-ring post structure. Comment: sample was probably from large structural timbers, either original or replacements (for which there is stratigraphic evidence), or a mixture of both. Date refers, therefore, only indirectly to building and destruction of structure, which must be younger than occupation of circular habitation enclosure (UB-187, etc.). This occupation is separated from concentric-ring post structure by layer of apparently sterile soil indicating period of disuse: duration of this period cannot be specified exactly from $\mathrm{C}^{14}$ dates but is unlikely to have been more than a few centuries.

UB-202. Navan Fort, concentric-ring post structure, 2 $2215 \pm 50$ 265 B.C.

Charcoal, small branches (partly Corylus, idl. by J.R.P.) from same stratigraphic horizon as UB-186. Comment: material was small hazel branches (though other woods may have been present); it seems that this was kindling material with which outer wall of concentric-ring post structure was fired. Date should refer to deliberate burning of structure. General Comment: this series is internally consistent and post-Neolithic occupations, to which dates relate, appear to have continued over several centuries. Time between means of oldest and youngest dates is some 400 yr. Occupations clearly belong to pre-Roman Iron age with possible initial utilization in Dowris phase of late Bronze age (Eogan, 1964). Early Iron age site at Lough Gara, Co. Sligo, yielded $\mathrm{C}^{\mathrm{ii}}$ dates covering roughly same range (Radiocarbon, 1961, v. 3, p. 26-38).

\section{Ballynagilly Series 1, Co. Tyrone, Northern Ireland}

The site, known as 'The Corby,' is in Ballynagilly Townland, Co. Tyrone, Northern Ireland (54 $42^{\prime} \times$ Lat, $6^{\circ} 51^{\prime} \mathrm{W}$ Long; Irish Grid 
Ref. H 743837) $5 \mathrm{mi} \mathrm{NW}$ of Cookstown. Series is from excavations carried out by A. M. ApSimon (Archaeol. Dept., Univ. of Southampton) on behalf of Ministry of Finance, Northern Ireland, during 1966-68 (Neolithic House in Ulster, 1968). Excavations revealed Neolithic settlement with rectangular house foundation and numerous hearths, pits, and postholes. Ca. $50 \mathrm{~m}$ from Neolithic site, Bell Beaker habitation site was discovered which yielded large quantities of flint implements and pottery. There are also signs of Early Bronze age utilization of site.

\section{UB-197. Ballynagilly, Neolithic borrow pit $5625 \pm 50$ (L, F135) \\ 3675 B.c.}

Charcoal (Pinus, id. by J.R.P.) from large pit containing hearth debris including burnt stone, burnt clay, and sherds of Neolithic pottery, ca. $7 \mathrm{~m} \mathrm{~S}$ of wall slot of Neolithic house (UB-201). Coll. 1967 by A.M.A. Comment (A.M.A.): assoc. pottery is of Dunmurry style (Case, 1961) tentatively placed at beginning of Irish Neolithic sequence.

\section{UB-201. Ballynagilly, Neolithic house wall-slot $\mathbf{5 1 6 5} \pm \mathbf{5 0}$ (L, F158) 3215 B.C.}

Charcoal (Quercus, id. by J.R.P.) from remains of split-oak planking compressed in wall-slot of Neolithic house. Coll. 1968 by J.R.P. Comment: date confirms Neolithic age of house, but is significantly younger than borrow-pit date (UB-197).

\section{UB-198. Ballynagilly, Early Bronze age hearth $\quad 3590 \pm 60$ (M, F33) \\ 1640 B.C.}

Charcoal from saucer-shaped mass of charcoal $40 \mathrm{~cm}$ diam. containing one Early Bronze age sherd and resting on burnt sandy clay with burnt Beaker artifacts. Coll. 1967 by A.M.A. Comment: sample should post-date Beaker pottery sherds below, and be applicable to Early Bronze age re-occupation.

\section{Ballynagilly Series II, Co. Tyrone, Northern Ireland}

Ballynagilly Series II samples relate to palaeoecologic work assoc. with excavations by A. M. ApSimon, as described under Ballynagilly Series I (this clate list). Samples come from several cores and monoliths taken by J.R.P. and A.G.S. from peat overlying occupation horizons and from nearby deep organic deposits. Detailed pollen analyses have been made of sub-samples from monoliths.

\section{UB-15. Ballynagilly, Monolith A, 22 to $24 \mathrm{~cm} \quad 3245$ B.C.}

Charcoal (Quercus, id. by J.R.P.) isolated from charcoal-rich layer in sandy peat. Pollen diagram shows temporary decline of Quercus curve; Pinus curve falls to low values and Betula curve rises. These and other features, together with presence of charcoal, suggest phase of forest clearance. Coll. 1966 by J.R.P. Comment: date is comparable with that of Neolithic house (UB-201). 
General Comment (Ballynagilly Series I and II): only small fraction of samples from Ballynagilly has been dated; it seems likely, however, that Neolithic occupation (or occupations) took place before 5000 radiocarbon yr ago. This is in line with other $\mathrm{C}^{14}$ dates for Neolithic material from Ireland (Radiocarbon, 1961, v. 3, p. 26-38; Watts, 1961) and with those for early Sub-boreal forest clearance at Fallahogy, Co. Londonderry (Radiocarbon, 1962, v. 4, p. 57-70; Smith and Willis, 1962).

\section{GEOLOGIC SAMPLE}

\section{UB-206. Drumskellan, Co. Donegal, Republic of $6955 \pm 100$ Ireland \\ 5005 B.C.}

Wood (Quercus, id. by J.R.P.) from raised beach at Drumskellan, Co. Donegal, Irish Republic (55 $5^{\circ} 5^{\prime} \mathrm{N}$ Lat, $7^{\circ} 15^{\prime} \mathrm{W}$ Long; Irish Grid Ref. C 5128). Sample from $\log 3$ to $4 \mathrm{~m}$ long embedded in low raised beach (4.9 to $6.1 \mathrm{~m}$ O.D.) shoreline of which notches gravels of slightly higher Late-glacial raised beach (Synge and Stephens, 1965, 1966). Coll. 1966 by E. A. Colhoun; subm. 1968 by N. Stephens, Geog. Dept., Queen's Univ. Belfast. Comment: beach cannot be older than date of sample. But, if wood was redeposited as driftwood beach could be younger. Trunk showed no signs of abrasion, and date agrees with conclusions of Synge and Stephens (1966). Pretreatment: sample ground and leached with $\mathrm{NaOH}$, washed, bleached in calcium hypochlorite, acidified with $\mathrm{HCl}$, and washed until neutral.

Date lists:

RFFERENCES

$\begin{array}{ll}\text { British Museum I } & \text { Barker and Mackey, 1959 } \\ \text { Cambridge V } & \text { Godwin and Willis, 1962 } \\ \text { Dublin I } & \text { McAulay and Watts, 1961 } \\ \text { Lund I } & \text { Håkansson, 1968 }\end{array}$

Lund I

Håkansson, 1968

Barker, Harold and Mackey, C. J., 1959, British Museum natural radiocarbon measurements I: Am. Jour. Sci. Radiocarbon Supp., 1959, v. 1, p. 81-86.

Case, H. J., 1961, Irish Neolithic pottery: distribution and sequence: Prehist. Soc. Proc., v. 27 , p. 174-233.

Eogan, G., 1964, The Later Bronze Age in Ireland in the light of recent research: Prehist. Soc. Proc., v. 30, p. 268-351.

Godwin, H. and Willis, E. H., Cambridge University natural radiocarbon measurements V: Radiocarbon, 1962 , v. 4 , p. $57-70$.

Håkansson, Sören, 1968, University of Lund radiocarbon dates I: Radiocarbon, 1968, v. 10 , p. $36-54$.

McAulay, I. R. and Watts, W. A., 1961, Dublin radiocarbon dates I: Radiocarbon, 1961 , v. 3, p. 26-38.

Neolithic house in Ulster: 1968, Nature, v. 220, p. 422-423.

Smith, A. G. and Willis, E. H., 1962, Radiocarbon dating of the Fallahogy Landnam phase: Ulster Jour. Archaeol., v. 24-25, p. 16-24.

Synge, F. M. and Stephens, N., 1965, Late Pleistocene shore lines and drift limits in north Donegal: Roy. Irish Acad. Proc., v. 64B, p. 131-153.

1966, Late- and Post-glacial shorelines, and ice limits in Argyll and northeast Ulster: Inst. British Geog. Trans. and Papers, 1966, publ. no. 39, p. 101-145.

Watts, W. A., 1961, C-14 dating and the Neolithic in Ireland: Antiquity, v. 34, p. 111116. 